\title{
AC 2010-38: ASSESSING THE EFFECTIVENESS OF DUAL DELIVERY MODE IN AN ONLINE INTRODUCTORY CIRCUITS ANALYSIS COURSE
}

\section{Amelito Enriquez, Canada College}

Amelito Enriquez is a professor of Engineering and Mathematics at Canada College in Redwood City, CA. He received a BS in Geodetic Engineering from the University of the Philippines, his MS in Geodetic Science from the Ohio State University, and his PhD in Mechanical Engineering from the University of California, Irvine. His research interests include technology-enhanced instruction and increasing the representation of female, minority and other underrepresented groups in mathematics, science and engineering. 


\title{
Assessing the Effectiveness of Synchronous Content Delivery in an Online Introductory Circuits Analysis Course
}

\begin{abstract}
A 2008 study released by the US Department of Education indicates that online enrollments are growing at substantially faster rates than overall higher education enrollments (12.9\% vs. 1.2\%), with over 3.9 million students (or over $20 \%$ of all U.S. higher education students) taking at least one online course in the fall of 2007. The study also reveals that among the eight major discipline areas examined, engineering has much lower online representation compared to others. One reason for this slow adoption of online teaching pedagogies in US engineering programs can be attributed to the perception by some engineering faculty and administrators that online courses are not equivalent in content and rigor when compared to the traditional, face-to-face courses. This paper presents the results of a study comparing the performance of on-campus and online students in a sophomore-level Circuits Analysis course in a public two-year institution. In this introductory course for all engineering majors, content is delivered simultaneously to oncampus students and online students (dual delivery mode) using a combination of Tablet PC functionality and Elluminate Live! software that allows synchronous delivery through the Internet, as well as recording and archiving of all classroom lecture sessions. Identical homework sets and tests were given to the two groups, and their performance compared. Results show that there is no statistically significant difference in the levels of performance of the two groups of students. Online students also rated their experience in this online class to be better than other online courses they have previously taken.
\end{abstract}

\section{Introduction}

Online teaching is one of the fastest growing trends in educational technology in the U.S. A 2008 study $^{1}$ released by the US Department of Education indicates that online enrollments are growing at substantially faster than overall higher education enrollments (12.9\% vs. 1.2\%), with over 3.9 million students (or over $20 \%$ of all U.S. higher education students) taking at least one online course in the fall of 2007 . The study also reveals that among the eight major discipline areas examined, engineering has much lower online representation compared to others. There have been many studies on the reasons why higher education faculty choose to adopt or refrain from adopting online teaching pedagogies ${ }^{2,3,4,5,6,7}$. Reasons for not participating in online instruction include concerns about academic integrity, and a perception by some faculty and administrators that online courses are not equivalent in content, rigor, and level of achievement of learning objectives when compared to the traditional, face-to-face courses ${ }^{7,8,9,10,11,12,13}$. 
There have been numerous studies done across various disciplines to determine the effectiveness of online teaching and learning $7,14,15,16,7,17,18,19,20,21,22,23$. The most comprehensive study to-date is a 2009 meta-analysis released by the US Department of Education ${ }^{24}$ which included a systematic search for experimental or quasi-experimental studies of the effectiveness of online learning published in the literature from 1996 to 2008. This meta-analysis concluded that "on average, students in online learning conditions performed better than those receiving face-to-face instruction." It should be noted that for studies included in this meta-analysis, the most common subject matter is medicine or health care. Other content areas include computer science, teacher education, social science, mathematics, languages, science and business. As with most previous studies on effectiveness of online instruction, engineering is not well represented.

Studies of the effectiveness of online teaching in engineering have been limited. A recent study ${ }^{25}$ found no difference between final exam scores in the hybrid sections and the face-to-face sections of an Engineering Graphics course. Although supporting the effectiveness of online instruction in engineering, the hybrid instruction studied includes considerable (once a week) face-to-face instruction. The online portion of the course included voiced-over content presentations, software demonstrations, and sketching examples. A similar study ${ }^{26}$ shows how the provision of online lectures, audiovisual material, discovery-based learning activities and communication tools can improve the effectiveness of subject content delivery in engineering. More studies on how online instruction in engineering can replace and be as effective as, or better than, traditional face-to-face instruction are needed.

The creation of virtual classroom space through the use of a synchronous learning environment to reduce "transactional" distance $\mathrm{e}^{27}$ has been shown to improve the quality of the educational experiences of online students ${ }^{28,29,30}$. This virtual classroom space can also be used to develop a dual mode of delivery to reach students online and on campus simultaneously. By assigning identical homework, exams, projects, and other course requirements to both groups of students, this dual delivery mode can address concerns regarding the equivalency of content and rigor in the online and on-campus formats. Although this dual mode of teaching also offers economic benefits, it demands extra effort from the instructor, and may prove disadvantageous for the online students ${ }^{31}$.

The purpose of this paper is to illustrate how a dual delivery mode (content being simultaneously delivered to face-to-face and online students) can be used effectively in engineering education and with very little extra effort from the instructor. In this study, the comparability of achieving student learning outcomes for online and on-campus students in an introductory sophomore-level Circuits Analysis course will be analyzed using two years worth of data. 


\section{Methodology}

To compare the effectiveness of dual delivery mode, specifically the comparability of the online and the on-campus courses, students in two sections each of online and on-campus formats of a sophomore-level Circuits course are compared. Comparisons of student performance in the course and usage of online resources available to both online and on-campus students are done. Additionally, a survey was administered to determine student perceptions and attitudes towards these resources and their levels of satisfaction with the course.

\subsection{The Circuits Class at Cañada College}

Cañada College is part of the 108-school California Community College system, and is one of the smallest community colleges in the San Francisco Bay Area with approximately 6,000 students. The college is a federally-designated Hispanic Serving Institution with approximately 42 percent Latino students. Cañada's Engineering Department is a two-year transfer program with approximately fifteen to twenty students transferring to a four-year institution every year. The Circuits course at Cañada College is a three-unit, sophomore-level lecture course required of all engineering students regardless of their majors, or their transfer institutions. The course is offered every spring semester. The class meets for three hours a week for sixteen weeks, and covers topics on theory and techniques of circuit analysis, circuit laws and nomenclature, resistive circuits, controlled sources, ideal operational amplifiers, natural and complete responses of first- and second-order circuits, steady-state sinusoidal analysis, power calculations, transformers, and three-phase circuits.

In spring semesters of 2008 and 2009, the course was offered at Cañada in dual delivery mode with lectures simultaneously delivered to on-campus and online students. All lecture notes are generated using a Tablet PC and are viewed by on-campus students through a computer projector, and synchronously by online students via the Internet.

Tablet PCs are essentially laptop computers that have the added functionality of simulating paper and pencil by allowing the user to use a stylus to write directly on the computer screen to create electronic documents that can be easily edited using traditional computer applications. This functionality makes Tablet PCs more suitable than laptop computers in presenting, solving and analyzing problems that require sketches, diagrams, and mathematical formulas. For the Circuits course at Cañada, the traditional blackboard used to generate class lecture notes has been completely replaced with the Tablet PC, allowing for synchronous delivery of content to on-campus and online students, as well as electronic copies of the lecture notes for later distribution and use.

Synchronous delivery of lectures to online students is achieved using Elluminate Live!, a multipoint videoconferencing software that is available for use free of charge to all faculty and 
staff of the California Community College system through CCC Confer, a project funded by a grant from the California Community Colleges Chancellor's Office. CCCC Confer allows the creation of a live interactive classroom that includes chat, electronic whiteboard, polls, quizzes and surveys, VoIP and web camera usage, application and desktop sharing, file transfer, as well presentation and sharing of documents, streaming audio and/or video. CCC Confer also allows for recording and archiving the entire session — from voice, to chat, to video, to pen strokes during the live class, allowing everything to be played back, verbatim, and with the capability to fast forward and rewind. It also allows for sessions to be closed-captioned for the hearing impaired while also reaching out to the visually impaired by offering compatibility with most screen readers to help institutions meet state and federal accessibility guidelines. CCC Confer has allowed users to overcome the challenges videoconferencing can have, such as limited scalability, dependency on IT support, and hardware requirements.

For the Circuits course at Cañada College, links to archived CCC Confer lectures, annotated lecture notes, and additional course materials such as homework problems and solutions, sample tests, discussion boards and news forums are made available to both online and on-campus students using Moodle, an open source Course Management System. Both the online and oncampus sections of the Circuits course use the same Moodle website so that all online resources are available to both groups of students.

\subsection{Comparison of Online and On-campus Students}

To increase the sample size of the data and hence improve the reliability of the statistical analyses done, enrollments in the Circuits classes from two successive spring semesters are combined. The 2008 Circuits class had 15 online students and 14 on-campus students, for a total of 29 students. The 2009 class had 10 online students and 16 on-campus students, for a total of 26 students. Combining these two dual-mode classes gives a total of 25 on-line students and 30 on-campus students.

Table 1 is a comparison of the demographics of the online and on-campus students. While both groups of students are ethnically diverse, the online group has a higher percentage of female students than the on-campus group (36.0\% vs. 10.0\%). Both groups have Mechanical Engineering as the major with the highest number of students. However, there are significantly fewer Electrical Engineering majors in the online group compared to the on-campus group (16.0\% vs. $30.0 \%$ ). In fact Electrical Engineering is second only to Mechanical Engineering in

popularity among the on-campus students while it is below Civil Engineering and Other among the online students, indicating that EE majors are less likely to take the class online. Additionally, a majority (83.3\%) of the on-campus students were taking the lab course concurrently with the lecture course while only $12.0 \%$ of online students did so. This is significant because the lab course (also held on campus) was designed to reinforce the concepts 
learned in the lecture. Hence, the on-campus students have an advantage over online students in that they are able to apply and experimentally verify concepts learned in the lecture course. It should be noted that in many California engineering programs, the Circuits Lab course is required of all $\mathrm{EE}$ majors but not the other engineering majors.

Table 1. Demographic comparison of On-campus and Online students.

\begin{tabular}{lrrrr}
\hline \multicolumn{2}{c}{ Online } & \multicolumn{2}{c}{ On-campus } \\
\hline Demographics & $\mathbf{N}$ & $\%$ & $\mathbf{N}$ & $\%$ \\
Gender & & & & \\
Female & 9 & $36.0 \%$ & 3 & $10.0 \%$ \\
$\quad$ Male & 16 & $64.0 \%$ & 27 & $90.0 \%$ \\
$\quad$ Total & 25 & & 30 & \\
Ethnicity & & & & \\
$\quad$ Afro-American & 1 & $4.0 \%$ & 0 & $0.0 \%$ \\
Asian & 7 & $28.0 \%$ & 10 & $33.3 \%$ \\
Caucasian & 10 & $40.0 \%$ & 8 & $26.7 \%$ \\
Hispanic & 5 & $20.0 \%$ & 7 & $23.3 \%$ \\
Other & 2 & $8.0 \%$ & 5 & $16.9 \%$ \\
$\quad$ Total & 25 & & 30 & \\
Major & & & & \\
Mechanical Engr & 8 & $32.0 \%$ & 12 & $40.0 \%$ \\
Civil Engr & 7 & $28.0 \%$ & 5 & $16.7 \%$ \\
Electrical Engr & 4 & $16.0 \%$ & 9 & $30.0 \%$ \\
Computer Engr & 0 & $0.0 \%$ & 2 & $6.7 \%$ \\
Other & 6 & $24.0 \%$ & 2 & $6.7 \%$ \\
$\quad$ Total & 25 & & 30 & \\
Taking Lab Class & & & & \\
$\quad$ Yes & 3 & $12.0 \%$ & 25 & $83.3 \%$ \\
No & 22 & $88.0 \%$ & 5 & $26.7 \%$ \\
$\quad$ Total & 25 & & 30 & \\
\hline
\end{tabular}

Table 2 summarizes the results of a survey given to online students to understand their reasons for taking online classes, as well as any previous history of taking online courses. For the 21 online students who completed the survey, schedule conflict and convenience were the most common reasons for taking the Circuits class online. Although CCC Confer allows for students to participate in the lectures synchronously via the Internet, a majority of the online students were not able to do so due to scheduling conflicts. Additionally, a majority of the students who completed the survey would not have been able to take the class if it were not offered online, with only $23.8 \%$ responding positively to being able to take the regular on-campus class. This is significant to the viability of the course and the Engineering program at Cañada College since without the online students, the class could have been cancelled due to low enrollment in both 2008 and 2009. The survey also indicates that a majority (over 75\%) of the students have taken at least one other online course. 
Table 2. Summary of the survey results for selecting online versus on-campus format, and previous history of taking online courses.

\begin{tabular}{lcc}
\hline Question & Count & Percentage \\
\hline What is (are) your primary reason(s) for taking this class online? & & \\
Schedule conflict with regular class & 12 & $57.1 \%$ \\
Convenience & 12 & $57.1 \%$ \\
Commute (I live far from Cañada College) & 8 & $38.1 \%$ \\
I prefer online over face-to-face & 3 & $14.3 \%$ \\
Other Reasons & 6 & $28.6 \%$ \\
Would you have been able to take this course if it were not online? & & \\
Yes & 5 & $23.8 \%$ \\
No & 13 & $61.9 \%$ \\
Maybe & 3 & $14.3 \%$ \\
Excluding this class, how many online classes have you taken at & & \\
Cañada, or any other institution? & & \\
Zero & 5 & $23.8 \%$ \\
One & 6 & $28.6 \%$ \\
2-5 classes & 8 & $38.1 \%$ \\
more than 5 & 2 & $9.5 \%$ \\
\hline
\end{tabular}

\subsection{Data Analysis}

To measure the effectiveness of the dual delivery mode for the Circuits course at Cañada as described above, the performance of the online and on-campus students were compared. Scores of the two groups of students on fifteen homework sets, four tests, and a final examination were compared. Identical homework problems were assigned from the textbook for both student groups. Due dates for all homework assignments were identical for the two groups of students with on-campus students submitting their work in class while online students uploaded their work through the class Moodle website. On-campus students also had the option of online submission, but this option was almost never used by on-campus students since it required an extra step of creating an electronic version of their work. All online students come to campus to take each of the four tests, as well as the final exam, either with the rest of the on-campus students, or in the campus Learning Center Testing facility. The average scores for the online and on-campus groups were computed and independent Student $t$-tests were used to evaluate the statistical significance of any differences in the performance levels of the two groups. The overall class retention and success rates were also compared.

To determine students' attitudes towards the use of Tablet PCs and the CCC Confer (Elluminate! Live), an attitudinal survey was given to both groups of students at the end of the semester. This survey was designed to determine students' perceptions of the effectiveness of the online resources and student use of these resources. Simple averages of student responses were computed to summarize the results, and independent Student $t$-tests were used to evaluate 
statistical significance of any observed differences in the responses of the two groups. Online students were also asked to compare their online experience in the Circuits class with other online courses that they have taken.

\section{Results}

\subsection{Class Performance Comparison}

Table 3 shows a comparison of the performance of the online and on-campus students. For this comparison, retention rate is defined as the percentage of students who did not withdraw from the class, and hence received a grade of either A, B, C, D, or F. Success rate is defined as the percentage of students who received a passing grade $(\mathrm{A}, \mathrm{B}$, or $\mathrm{C})$. The retention rates are almost the same with four students dropping from each group. The success rate of $80.0 \%$ is identical for the two groups. The online group had slightly higher Homework Average, Final Exam, and Final Course Grade, and a slightly lower Test Average compared to the on-campus students. However, there is no statistically significant difference in any of these statistics between the online and on-campus groups indicating that the online students did as well as the on-campus students.

Table 3. Comparison of the performance of online and on-campus students.

\begin{tabular}{lccc}
\hline & $\begin{array}{c}\text { Online } \\
(\mathrm{N}=25)\end{array}$ & $\begin{array}{c}\text { On-Campus } \\
(\mathrm{N}=30)\end{array}$ & $\begin{array}{c}\text { Difference } \\
(\mathrm{OL}-\mathrm{OC})\end{array}$ \\
\hline Retention Rate & $84.0 \%$ & $86.7 \%$ & $-2.7 \%$ \\
Success Rate & $80.0 \%$ & $80.0 \%$ & $0.0 \%$ \\
Homework Average & $83.5 \%$ & $82.0 \%$ & $1.5 \%$ \\
Test Average & $77.7 \%$ & $78.3 \%$ & $-0.6 \%$ \\
Final Exam & $79.8 \%$ & $79.0 \%$ & $0.8 \%$ \\
Final Course Grade & $79.1 \%$ & $79.0 \%$ & $0.1 \%$ \\
\hline
\end{tabular}

\subsection{End-of-Semester Survey}

Table 4 shows a summary of the end-of-semester survey given to both online and on-campus students to determine their attitudes towards and usage of class materials and resources. Both online and on-campus students viewed the available resources positively, finding lecture notes prepared using Tablet PCs useful, Moodle (Web Access) intuitive and easy to use, archived CCC Confer lectures and CCC Confer online office hours useful, with responses of mostly between "Strongly Agree" and "Agree" when asked about the usefulness of these resources. Both groups of students preferred lectures with notes created using Tablet PCs over those using blackboard and chalk. There is no significant difference in the responses of the two groups of students in all but one survey question. When asked how they agree with the statement "I download archived 
CCC Confer lectures regularly," the online students' average response was 4.43 (between "Strongly Agree" and "Agree") while the on-campus students' average response was 3.27 (between "Agree" and "Neutral). The difference in the responses of these two groups is statistically significant [independent Student $t$-test: $t(1,42)=4.59, p<.0001)$ ].

Table 4. Summary of results of end-of-semester attitudinal survey.

\begin{tabular}{lccc}
\hline $\begin{array}{l}\text { Response Scale: 5 - Strongly Agree, 4 - Agree, } \\
3 \text { - Neutral; 2 - Disagree, 1 - Strongly Disagree. }\end{array}$ & $\begin{array}{c}\text { Online } \\
\text { (N=21) }\end{array}$ & $\begin{array}{c}\text { On-Campus } \\
\text { (N=26) }\end{array}$ & $\begin{array}{c}\text { Difference } \\
\text { (OL - OC) }\end{array}$ \\
\hline $\begin{array}{l}\text { I find the posted instructor's lecture notes (prepared } \\
\text { using Tablet PCs) useful. }\end{array}$ & 4.63 & 4.8 & 0.17 \\
$\begin{array}{l}\text { Having access to posted notes promoted my } \\
\text { learning. }\end{array}$ & 4.63 & 4.82 & 0.20 \\
$\begin{array}{l}\text { I review the posted POWERPOINT Lecture Notes } \\
\text { to do homework and/or study for tests. }\end{array}$ & 4.68 & 4.68 & 0.00 \\
$\begin{array}{l}\text { I prefer lectures with notes created using Tablet PCs } \\
\text { over those using blackboard and chalk. }\end{array}$ & 4.05 & 4.28 & 0.23 \\
$\begin{array}{l}\text { I find Web Access intuitive and easy to use. } \\
\begin{array}{l}\text { The archived CCC Confer lectures are useful to me } \\
\text { when doing homework and/or studying for tests. }\end{array}\end{array}$ & 4.83 & 4.58 & -0.25 \\
$\begin{array}{l}\text { I download and review archived CCC Confer } \\
\text { lectures regularly. }\end{array}$ & 4.43 & 4.37 & 0.10 \\
$\begin{array}{l}\text { I find online office hours held using CCC Confer } \\
\text { useful. }\end{array}$ & 3.95 & 4.27 & $1.16^{*}$ \\
$\begin{array}{l}\text { I would like to have CCC Confer online office hours } \\
\text { available for my other courses. }\end{array}$ & 4.29 & 4.04 & -0.09 \\
\hline
\end{tabular}

*Statistically significant $[t(1,42)=4.59, p<.0001)]$.

Since the accessing the archived CCC Confer lectures is the only area where a statistically significant difference in the responses of online and on-campus students was measured, further investigation is done. Table 5 summarizes the self-reported frequency with which online and oncampus students downloaded CCC Confer. Among online students, $66.7 \%$ indicated that they downloaded the archives regularly every week, as opposed to only $15.4 \%$ among on-campus students. The last row of Table 5 shows the average number of times these lecture archives were downloaded by each group of students as determined from actual CCC Confer records. On the average, online students downloaded CCC Confer lectures 22.5 times over the semester while on-campus students, on average, downloaded the archives only 3.8 times the entire semester. The difference between the number of times online students and on-campus students download the archives is statistically significant $[t(1,22)=4.47, p<.0001)]$. 
Table 5. Difference in frequency of access of archived CCC Confer lectures by online and oncampus students.

\begin{tabular}{lcc}
\hline $\begin{array}{l}\text { I download and review archived } \\
\text { CCC Confer lectures: }\end{array}$ & $\begin{array}{c}\text { Online } \\
(\mathrm{N}=21)\end{array}$ & $\begin{array}{c}\text { On-Campus } \\
(\mathrm{N}=26)\end{array}$ \\
\hline Regularly every week & $66.7 \%$ & $15.4 \%$ \\
$\begin{array}{l}\text { Frequently (about every other week) } \\
\text { Sometimes (about once a month) }\end{array}$ & $14.3 \%$ & $30.8 \%$ \\
$\begin{array}{l}\text { Almost never (once or twice the } \\
\text { whole semester) }\end{array}$ & $14.3 \%$ & $26.9 \%$ \\
$\begin{array}{l}\text { Never } \\
\text { Actual average number of times } \\
\text { archives were downloaded }\end{array}$ & $4.8 \%$ & $19.2 \%$ \\
\hline
\end{tabular}

*The difference, 18.7 , is statistically significant $[t(1,22)=4.47, p<.0001)]$.

\subsection{Comparison of Online Circuits Class to Other Online Classes}

The end-of-semester survey also asked online students to rate their opinion of the Cañada College online Circuits class by comparing their experience in the course relative to other online classes that they have taken. Table 6 summarizes the responses of online students when asked to compare the Circuits online class to other online courses they have taken. All 16 online students who have taken other online courses indicated that the online Circuits class was much better or better compared to other online courses they have taken, with 13 out of $16(81.3 \%)$ rating the Cañada Circuits class to be much better.

Table 6. Comparing Online Circuits class with other online courses.

\begin{tabular}{lcc}
\hline Response & Count & Percent \\
\hline Much better & 13 & $61.9 \%$ \\
Better & 3 & $14.3 \%$ \\
About the same & 0 & $0.0 \%$ \\
Worse & 0 & $0.0 \%$ \\
Much Worse & 0 & $0.0 \%$ \\
No Opinion (no other online & 5 & $23.8 \%$ \\
courses taken) & 5 & \\
\hline
\end{tabular}

\section{Analysis and Conclusion}

Results of the present study show that an online engineering course can be as effective as the traditional on-campus, face-to-face format. The retention rates are almost the same for the online 
and on-campus groups, and the success rates are identical. There is no statistically significant difference in the levels of performance of the two groups.

It should be noted that the demographic distribution of students is more favorable for the oncampus group to do better in the Circuits course compared to the online group. The percentage of Electrical Engineering majors $(30.0 \%)$ in the on-campus group is about twice of that in the online group (16.0\%). The Circuits course is the first course in Electrical Engineering (EE), and is therefore more important to EE majors than to students majoring in other fields of engineering. It can also be inferred that the perceived importance of the Circuits course to EE majors may be one of the reasons why fewer of them take the class online. Another advantage of the on-campus group is the number of students who were concurrently taking the laboratory class for Circuits. A majority $(83.3 \%)$ of on-campus students were taking the Circuits lecture and laboratory courses simultaneously while only $12 \%$ of the online students were enrolled in the laboratory class. The laboratory class gives students opportunities to apply and experimentally verify concepts learned in the lecture course. In spite of the more favorable demographics of the oncampus group (more EE majors and more students taking the lab course), the on-line students have slightly higher (although not statistically significant) scores in homework, final exam and final course grade.

Although CCC Confer allows online students to participate in the lecture sessions synchronously via the Internet, a majority of them were not able to do so due to scheduling conflicts. To understand how the online students were able to perform as well (if not better) than the oncampus students despite not being able to attend lectures, and despite a less favorable demographics, a comparison of student usage of available class resources was done. Online students downloaded archived CCC Confer lectures about six times more frequently than oncampus students (22.5 times for online and 3.8 times for on-campus). These downloadable archived lectures allow for more flexibility in viewing through features such as rewind, fast forward, pause, etc., giving students more control of the learning process compared to listening to a live lecture. Results of previous research indicate that "conditions in which learners have more control of their learning produce larger learning gains than do instructor-directed conditions" ${ }^{24}$. For instance, a study done by Zhang ${ }^{23}$ showed that simply giving students the ability to randomly access materials, allowing them to watch videos in any sequence, and to rewind and fast forward through their content, resulted in a statistically significant positive gain in learning. For the Circuits course at Cañada, even though such functionality is available to both online and on-campus students, the on-campus students rarely accessed these archived lectures.

The online students also found their learning experience in the Cañada College Circuits course better than other online courses that they have taken. A majority of them indicated that the online experience was enhanced by availability of the archived CCC Confer lectures, and the 
students' ability to review the archives at their own pace. It should be noted that most of the online students would not have been able to take the on-campus section of the class, and would not have been able to complete their lower-division requirements and transfer to a four-year institution in a timely manner without the online option. This is especially important for minority and female students whose pursuit of demanding professions, such as engineering and the physical sciences, are negatively affected by financial difficulties and demanding family obligations ${ }^{32,33}$. It should also be noted that the higher percentage of female students in the Cañada online class could be attributed these family obligations; three of the female online students are married, two of them taking care of young kids while taking the class.

Although the sample sizes used in the present study are small, results indicate that the use of dual delivery mode to synchronously deliver course content to on-campus and off-campus students can be an effective way of increasing teaching efficiency. This is particularly important for small engineering programs (particularly those in community colleges) where budget cuts and low enrollments threaten the viability of course offerings and entire engineering programs. For California community colleges in particular, this can be accomplished without any extra costs through CCC Confer.

\section{Acknowledgements}

This project was partly supported by a grant from the US Department of Education through the Minority Science and Engineering Improvement Program (MSEIP, Award No. P120A080080). The author would also like to thank Donna Gustafson and Elane Torrisi of CCC Confer, and Jasmine Witham of San Mateo County Community College District for providing technical assistance to obtain data needed for this project.

\section{Bibliography}

1. Allen, I. E., \& J. Seaman (2008). Staying the Course: Online Education in the United States, 1008. Needham MA: Sloan Consortium

2. Beaudoin, M.R. (1990). The instructor's changing role in distance education. The American Journal of Distance Education, 4(2), 21-29.

3. Bower, B.L (2001). Distance education: facing the challenge. Online Journal of Distance Learning Administration, Volume (2) 2, retrieved August 22, 2009 from: http://www.westga.edu/ distance/ojdla/summer42/bower42.html.

4. Clark, T. (1993). Attitudes of higher education faculty toward distance education: A national survey. The American Journal of Distance Education, 7(2), 19-33.

5. McKenzie, B. K., Mims, N., Bennett, E., \& Waugh, M. (1999, Fall). Needs, concerns, and practices of online instructors. Online Journal of Distance Learning Administration, 2(3). Retrieved October 3, 2009 from: http://www.westga.edu/ distance/ojdla/fall33/mckenzie33.html 
6. Rockwell, K., Schauer, J., Fritz, S.M., \& Marx, D.B. (1999). Incentives and obstacles influencing higher education faculty and administrators to teach via distance. The online Journal of Distance Learning Administration, 2(3): Winter. Retrieved August 30, 2009 from http://www.westga.edu/ distance/ojdla/winter24/rockwell24.html.

7. Schifter, C.C. (2002). Perception differences about participating in distance education. Online Journal of Distance Learning Administration, 5 (1). Retrieved October 2, 2009 from http://www.westga.edu/ distance/ojdla/spring51/schifter51.html.

8. Adams, J. (2008). Understanding the Factors Limiting the Acceptability of Online Courses and Degrees. International Journal on E-Learning. 7 (4), pp. 573-587. Chesapeake, VA: AACE.

9. Oomen-Early, J. \& Murphy, L. (2009). Self-Actualization and E-Learning: A Qualitative Investigation of University Faculty's Perceived Barriers to Effective Online Instruction. International Journal on E-Learning. 8 (2), pp. 223-240. Chesapeake, VA: AACE.

10. Page, K. E. (2000). The integration of on-line instruction into a Kansas community college: A naturalistic study. (Doctoral dissertation, University of Kansas, 2000). Dissertation Abstracts International, 61, 08A.

11. Russell, T.L. (1999). The no significant difference phenomenon. Raleigh: North Carolina State University.

12. Wallace, T.L. (2002). Reducing face-to-face instructor contact time with Web-based and Web-enhanced instruction. An examination of achievement and attitudes of undergraduate students in a pre-service teacher education course. (Doctoral dissertation, University of South Florida, 2002). Dissertation Abstracts International, 63, 05A.

13. Wilson, C (2001). Faculty attitudes about distance learning. Educause Quarterly, 2, 70-71.

14. Connolly,T., MacArthur, E., Stansfield, M. \& McLellan, E. (2007). A Quasi-Experimental Study of Three Online Learning Courses in Computing. Computers \& Education, v49 n2 p345-359 Sep 2007.

15. Jang, K.S., Hwang, S.Y., Park, S.J., Kim, Y.M., \& Kim, M.J. (2005). Effects of Web-based teaching method on undergraduate nursing students' learning of electrocardiography. The Journal of Nursing Education. 44(1):3539.

16. Mentzer, G.A., Cryan, J, and Teclemaimanot, B. (2007). A comparison of face-to-face and Web-based classrooms. Journal of Technology and Teacher Education, 15(2):233-46.

17. Schulman, A. H., \& Sims. R. L. (1999). Learning in an online format versus an in-class format: An experimental study. THE Journal, 26(11), 54-56.

18. Sener, J., \& Stover, M.S. (2000). Integrating ALN into an independent study distance education program: NVCC case studies. Journal of Asynchronous Learning Networks, 4(2).

19. Sitzmann, T., Karaiger, K., Stewart, D., and Wisher, R. (2006). The comparative effectiveness of Web-based and classroom instruction: A meta-analysis. Personnel Psychology 59:623-64.

20. Smeaton, A. \& Keogh, G. (1999). An analysis of the use of virtual delivery of undergraduate lectures. Computers and Education. 32, 83-94.

21. Vroeginday. B.J. (2005).Traditional vs. online education: A comparative analysis of learner outcomes. (Doctoral dissertation, Fielding Graduate University, 2005). Dissertation Abstracts International, 66, 10A.

22. Warren, L.L., \& Holloman, H.L. (2005). On-line Instruction: Are the outcomes the same? Journal of Instructional Psychology. 32(2), 148-152.

23. Zhang, D. (2005). Interactive multimedia-based e-learning: A study of effectiveness. American Journal of Distance Education 19(3):149-62.

24. U.S. Department of Education, Office of Planning (2009). Evaluation and Policy Development. Evaluation of Evidence-Based Practices in Online Learning: A Meta-Analysis and Review of Online Learning Studies, Washington, D.C.

25. Branoff, \& T., Weibe, E. (2009). Face-to-Face, Hybrid, or Online?: Issues Faculty Face Redesigning an Introductory Engineering Graphics Course, Engineering Design Graphics Journal 73(1):25-31.

26. Blicblau, A.S. (2006). Online Delivery Management for Teaching and Learning (EJ831917). European Journal of Engineering Education, 31(2):237-246. 
27. Moore, M. G., \& Kearsley, G.(1996). Distance education: A systems view. Belmont, CA: Wadsworth.

28. McBrien, J.L, Jones, P., and Cheng, R. (2009), Virtual Spaces: Employing a Synchronous Online Classroom to Facilitate Student Engagement in Online Learning, International Review of Research in Open and Distance Learning, 10(3). Retrieved August 22, 2009 from http://www.irrodl.org/index.php/irrodl/article/viewFile/605/1298.

29. Murphy, E., Ciszewska-Carr, J. (2007) Instructors' Experiences of Web Based Synchronous Communication using Two Way Audio and Direct Messaging, Australasian Journal of Educational Technology, 23(1), 68-86.

30. Tremblay, R. (2006) "Best Practices" and Collaborative Software in Online Teaching, International Review of Research in Open and Distance Learning, v7 n1, 1-5. Retrieved August 22, 2009 from http://www.irrodl.org/index.php/irrodl/article/viewFile/309/513.

31. Popov, O. (2009) Teachers' and Students' Experiences of Simultaneous Teaching in an International Distance and On-Campus Master's Programme in Engineering, International Review of Research in Open and Distance Learning, v10 n3. Retrieved August 22, 2009 http://www.irrodl.org/index.php/irrodl/article/viewFile/669/1304.

32. Kealing, J. (n.d.). Minority women and higher education. Retrieved May 10, 2008 from http://asstudents.unco.edu/students/AE-Extra/2001/1/MinorityWomen.html

33. Seymour, E. and Hewitt, N.M. (1997). Talk about leaving: Why undergraduates leave the sciences. Boulder, CO: Westview Press. 